\title{
MENGENALKAN JIWA WIRAUSAHA PADA ANAK SEJAK DINI MELALUI PENDIDIKAN INFORMAL
}

\author{
Dewi Purwaningsih ${ }^{1}$, Nani Al Muin ${ }^{2}$ \\ Fakultas Ilmu Pendidikan dan Ilmu Pengetahuan Sosial \\ Universitas Indraprasta PGRI \\ dpurwaningsih758@gmail.com,nanialmuin04@gmail.com
}

Dikirim : 21 Juni 2021 Direvisi : 30 Juni 2021 Dipublikasi : 30 Jun 2021

\begin{abstract}
ABSTRAK
Mengenalkan jiwa wirausaha pada usia anak sejak dini merupakan peranan yang sangat penting dalam meningkatkan kemandiriannya dan memiliki manfaat yang sangat bagus dan akan berpengaruh untuk masa depannya kelak. Bagaimana cara yang tepat untuk membangun jiwa wirausaha untuk anak usia dini dan metode apa yg tepat diterapkan. Sementara mengenalkan dan menumbuhkan jiwa wirausaha tidak bisa dilakukan secara nstant kepada anak usia dini untuk itu dan peranan orangtua disinilah sangat mendukung untuk pembentukan karakter seorang wirausaha dikemudian hari. Penelitian ini menggunakan pendekatan kualitatif dengan kajian deskriptif eksplanantif analitis, metode ini mengambarkan fakta pentingnya membangun jiwa wirausaha untuk anak usia dini. Tujuan penelitian ini untuk mengkaji tentang manfaat membangun jiwa wirausaha terhadap anak usia dini melalui pengembangan pendidikan informal dan penelitian ini hanya sebatas penanaman jiwa wirausaha didalam keluarga dan lingkungan terdekatnya. Melalui pelatihan kewirausahaan pada anak sejak dini adalah untuk menumbuhkan rasa percaya diri, mandiri dan menjadi orang yang memiliki kreatifitas yang tinggi sehingga menjadi lebih produktif pada saat dewasa nantinya. Pendidikan Informal sangat berpengaruh dalam pengembangan sikap dan karakter menjadi seorang wirausaha.
\end{abstract}

Kata Kunci : Jiwa wirausaha, Kewirausahaan, Pendidikan informal. 
Vol 2, No. 1 (2021), Juni 2021

E-ISSN: 2746-2471, DOI:

\section{A. PENDAhULUAN}

Tingkat pengangguran saat ini semakin meningkat sejak adanya wabah Covid-19 yang ada diseluruh dunia khususnya negara kita Indonesia merupakan salah satu negara yang memiliki dampak yang sangat berpengaruh dalam sektor ekonomi akibat wabah covid-19 ini. Tingkat penganguran terbuka berdasarkan data dari BPS atau Badan Pusat Statistik mencapai 7,07 persen dari 138,22 juta jiwa dari angkatan kerja. Dalam artian terdapat 9,77 juta penduduk di Indonesia merupakan pengangguran terbuka. Dengan banyaknya pengangguran tersebut maka muncullah para wirausahawan wirausahawan baru untuk menjalankan suatu usaha,tapi sayangnya masih banyak juga dari mereka yang tidak bisa bertahan dikarenakan belum memiliki mental jiwa wirausaha yang kuat.

Untuk memiliki jiwa wirausaha yang kuat perlu ditanamkan sejak dini, mengenalkan jiwa wirausaha sejak dini akan membantu melatih kepercayaan diri,cara berkomunikasi dengan baik, produktivitas dan kemandirian, tidak sedikit para pengusaha pemula yang baru saja menjalankan bisnisnya gagal karena kurang kepercayaan dirinya untuk menawarkan suatu produk, komunikasinya yang tidak efektif tujuannya dan mereka akan gampang menyerah sehingga usahanya putus ditengah jalan dan tidak seperti yang diharapkan, untuk itulah jiwa wirausaha sejak dini mulai kita kenalkan kepada anak anak kita dari mulai mereka mengenal belajar dengan teman teman dan lingkungan disekitarnya untuk masa depan mereka kelak agar bisa terbentuknya sumber daya manusia yang berkualitas, kreatif serta inovatif dan bisa menciptakan lapangan kerja untuk kemajuan bangsa dan negaranya

Seorang wirausaha bisa menciptakan lapangan pekerjaan dan akan membantu perekonomian yang baik di negaranya, dengan menjadi seorang wirausaha yang berhasil dan bisa meningkatkan perekonomian di suatu negara, mereka harus benar benar memiliki kemampuan yang mendukung untuk menjadi seorang wirausaha, untuk itu peranaan orangtua sangat penting dalam mengenalkan jiwa wirausaha.

\section{B. KAJIAN PUSTAKA}

Kata kewirausahaan merupakan gabungan dari bagian kata wira dan usaha, yang berarti wira merupakan pejuang, pahlawan, berani, berbudi luhur, dan berwatak agung. Sedangkan menurut kamus besar Bahasa Indonesia kata usaha merupakan bekerja, membuat sesuatu, menghasilkan produk dan memasarkannya, jadi dengan kata lain wirausaha merupakan sebuah proses dalam melakukan atau menciptakan sesuatu produk ataupun jasa secara kreatif dan inovatif untuk memberikan manfaat kepada orang lain dan memiliki nilai tambah sehingga bisa menghasilkan keuntungan untuk mencapai tujuan yang sudah ditetapkan.

Pengertian kewirusahaan menurut F. Drucker adalah kemampuan seseorang dalam membuat sesuatu yang baru dan dan berbeda dari yang sudah ada. Konsep kewirausahaan yang merujuk pada sifat, watak, dan ciri-ciri yang melekat pada diri 


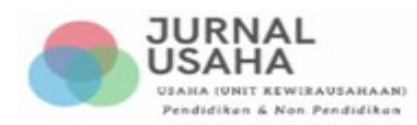

Vol 2, No. 1 (2021), Juni 2021

E-ISSN: 2746-2471, DOI:

seseorang yang memiliki kemauan keras dalam mewujudkan gagasan yang inovatif ke dalam dunia usaha yang benar benar nyata dan dapat dikembangkan dengan tangguh (Anwar, 2014).

Wirausaha yang berhasil dan sukses merupakan hasil dari interaksi dengan lingkungan disekitarnya, mereka berkembang karena memiliki pengetahuan yang selalu diupgrade, seorang wirausaha memiliki pengalaman yang sangat luar biasa dan memiliki sifat pantang menyerah dalam menghadapi setiap ganguan disekitar lingkungannya, semua itu mereka jadikan pelajaran untuk menjadi lebih baik lagi dalam menyelesaikan suatu masalah, semua itu mereka dapatkan dengan berinteraksi dengan lingkungan disekitarmya, karena itulah lingkungan sangat mendukung akan kemajuan dan suksesnya seorang wirausaha

Seorang Wirausaha yang memiliki jiwa kewirausahaan merupakan suatu modal dasar dalam menghasilkan suatu output atau hasil yaitu berupa kinerja atau keberhasilan usaha. Jiwa kewirausahaan harus dimiliki oleh seorang wirausaha karena jiwa wirausaha merupakan suatu modal dasar yang sangat diperlukan dalam menghadapi kehidupan di era global yang penuh persaingan yang sangat ketat dan penuh ketidakpastian ini. Dalam persaingan tersebut sangat diperlukan sikap- sikap ulet dan tangguh, kreatif, inovatif, dinamis, produktif, etos kerja keras,, efisien, disiplin, visioner, antisipatif, mampu menciptakan peluang baru,berani mengambil resiko, berani mengambil keputusan yang tepat untuk memperkecil resiko yang akan dihadapi

Menurut Sumarti (2008) yang menyatakan bahwa kewirausahaan adalah merupakan jiwa yang bisa diajarkan dan bisa dipelajari. Dari pernyataan tersebut diatas dapat disimpulkan bahwa wirausaha itu bisa dipelajari dan diajarkan dan bisa tumbuh dengan cara mengenalkan jiwa wirausaha pada anak-anak sejak dini, dengan mengenalkan jiwa wirausaha sejak dini akan memberikan banyak manfaat untuk masa depannya kelak . Dalam tahapan usia dini, anak-anak yang mengenal dan belajar wirausaha akan tumbuh menjadi pribadi yang kreatif dan inovatif dibandingkan dengan anak yang belum dikenalkan jiwa wirausahanya, anak yang mempelajari dan mengenal jiwa wirausaha akan terlihat lebih kreatif dengan berbagai kegiatan kegiatan kewirausahaan yang dilakukan di dalam lingkungannya baik dalam keluarga dan sekitar lingkungannya untuk meningkatkan tumbuh kembangnya dalam bidang wirausaha dan kegiatan inilah yang akan menjadi modal utama produktivitas dan kemandirian jika anak dewasa

\section{Pendidikan Anak Usia Dini}

Pendidikan nasional memiliki fungsi untuk bisa mengembangkan kemampuan dan membentuk watak anak didiknya untuk menciptakan sumber daya manusia yang memiliki potensi yang luar biasa untuk kemajuan suatu negara (Undang-undang sisdiknas, nomor 20, th 2003). Dengan demikian Pendidikan nasional harus memiliki sistem yang bisa menjamin pemerataan seluruh masyarakat untuk mendapatkan kesempatan dalam menerima pendidikan yang bermutu serta 


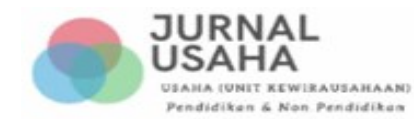

Vol 2, No. 1 (2021), Juni 2021

E-ISSN: 2746-2471, DOI:

perubahan yang bisa berpengaruh dalam peningkatan mutu yang sesuai dengan adanya perubahan yang bisa mengikuti perkembangan jaman,sehingga perlu adanya perencanaan yang terstruktur dan terarah untuk bisa menghadapi perubahan nasional maupun global secara berkesinambungan.

Sementara pendidikan merupakan segala pembelajaran untuk mendapatkan ilmu pengetahuan, berbagai keterampilan, yang diberikan oleh seorang mentor atau guru memulai pengajaran, pelatihan ataupun penelitian dalam sekelompok orang atau individu. Dengan adanya pendidikan tersebutlah sikap dan perilaku seorang bisa berubah melalui tahapan ataupun suatu proses pendewasaan pikiran dalam usaha pembelajaran tersebut.

Pendidikan anak usia dini adalah pembelajaran masa Pra sekolah yang diberikan oleh anak anak sejak lahir hingga mereka berusia enam tahun keatas dengan cara memberikan suatu rangsangan ataupun stimulasi kepada mereka untuk membantu tumbuh kembangnya secara jasmani dan rohani agar mereka memiliki kesiapan dalam memasuki jenjang pendidikan selanjutnya

Perlu diketahui pendidikan anak pada usia dini merupakan salah satu bentuk penyelenggaraan pendidikan yang menitikberatkan dalam peletakan dasar ke arah pertumbuhan dan 6 (enam ) perkembangan, yaitu : agama, moral, perkembangan fisik (koordinasi motorik halus dan kasar), kecerdasan/kognitif (daya pikir, daya cipta), sosio emosional (sikap dan emosi), bahasa dan komunikasi serta seni disesuaikan dengan tahapan perkembangan usia anak. Dengan demikian semua perlakuan pembelajaran yang diberikan pada usia anak sejak dini akan tertanam kuat dalam hati dan pikiran mereka masing masing, dan dari situlah watak mereka dapat terlihat dan bisa bekembang sesuai dengan yang kita arahkan. Melalui metode penanaman pendidikan informal menumbuhkan jiwa kewirusahuahan bagi anak usia dini akan membantu generasi muda bagi bangsa Indonesia yang baik dan bisa diandalkan sehingga bisa menjadi masyarakat yang mandiri, kreatif inovatif dan kredibel dan mampu berkompetitif di masa mendatang memajukan bangsa Indonesia. Menurut penelitian Ni Made Ayu Suryaningsih (2020) dengan judul Implementasi Metode Experiential Learning dalam Menumbuhkan Perilaku Kesehatan dan Keselamatan Anak Usia Dini menjelaskan bahwa perkembangan anak usia dini merupakan suatu periode siklus yang sangat sensitif dengan pertumbuhan dan perkembangannya yang sangat cepat. Seorang anak yang memiliki asupan protein dan makanan yang bergizi akan sangat berdampak terhadap pertumbuhan dan perkembangan pola pikirnya. Lingkungan yang sehat juga merupakan faktor yang sangat penting dalam membantu perkembangan anak sejak dini secara optimal

Tahapan yang paling penting dalam pertumbuhan dan perkembangan seorang anak adalah pada masa golden age atau yang lebih dikenal dengan masa keemasan sejak anak baru lahir hingga mencapai umur 2 tahun , dimana dalam masa tersebut masa yang paling penting dalam tahapan tumbuh kembangnya seorang anak dan sangat diperlukan perhatian khusus dari orang tuanya. Pada masa golden age inilah pertumbuhan dan perkembangan anak bertambah secara maksimal. Sikap dan 


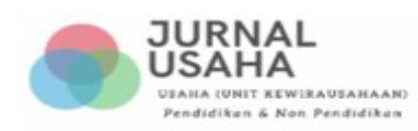

Vol 2, No. 1 (2021), Juni 2021

E-ISSN: 2746-2471, DOI:

pembentukan kepribadian akan sangat berpengaruh pada masa tersebut, jika orang tua tidak peka atau mengabaikan pada masa golden age akan sangat dikhawatirkan mengalami masalah pada tumbuh kembang anak tersebut, untuk itulah peran orang tua sangat berpengaruh besar dalam mengenal tahapan golden age untuk memberikan stimulasi yang sesuai dengan apa yang dibutuhkan oleh anak pada masa pertumbuhan tersebut.

Di Indonesia pada prakteknya pendidikan terbagi menjadi tiga yaitu pendidikan formal, pendidikan non formal, dan pendidikan informal. Contoh pendidikan formal usia dini seperti Taman Kanak kanak (TK), Pendidikan Anak Usia Dini (PAUD), Sekolah Dasar (SD), Sekolah Menengah Pertama (SMP), Sekolah Menengah Atas (SMA), Universitas, Institut dan lembaga yang sederajat . Sedangkan Pendidikan nonformal seperti bimbingan kursus ,pelatihan dan bimbingan belajar lainnya, sedangkan pendidikan informal meliputi pendidikan dalam keluarga dan masyarakat dan lingkungan sekitarnya.

Selanjutnya untuk tulisan ini mengkaji tentang bagaimana membangun jiwa kewirausahaan terhadap anak usia dini melalui pengembangan pendidikan informal, dan pengenalan yang dilakukan melalui keluarga, lingkungan, teman bermain, media telekomunikasi (Internet, Youtube, Instagram, Facebook dan lain lain)

\section{Pendidikan Informal Menumbuhkan Jiwa Wirausaha Bagi Anak Usia Dini}

Perlu menjadi perhatian kita Pendidikan dalam keluarga merupakan pendidikan internal pertama kali yang kita dapatkan misalkan ibu mengajarkan anak untuk berjalan, adab makan, ibadah sementara dan pendidikan dalam lingkungan secara eksternal merupakan pendidikan selanjutnya setelah keluarga. hal seperti ini tentunya sudah menjadi pemahaman secara umum dan bisa kita jumpai dalam kehidupan kita sebagai mahluk sosial, di dalam lingkungan masyarakatlah kita bisa mengenal berbagai sikap dan karakter setiap orang dengan cara kita bersosialisasi dengan masyarakat di sekitar lingkungan adapun pendidikan informal yang dilakukan dalam keluarga untuk menumbuhkan jiwa wirausaha bagi anak bisa dimulai dari melakukan permainan melalui game misalnya dengan melakukan permainan tersebut bisa meningkatkan daya pikir anak untuk bisa memecahkan suatu masalah yang akan dihadapinya kelak, dan masih banyak permainan yang bisa menumbuhkan jiwa wirausaha sebagai salah satu Pendidikan secara informal.

Selanjutnya Pendidikan kewirusahaan merupakan proses pembelajaran dalam membentuk jiwa dan mental seorang wirausaha sehingga sebagai seorang pengusaha lebih bisa memahami perencanaan produksi, manajemen SDM, keuangan, dan terkait perencanaan produk (Modul Kewirausahaan, 2012) hingga saat saat ini pendidikan kewirausahaan ini semakin marak dan bahkan sudah menjadi trend disetiap jenjang pendidikan baik itu formal non formal dan informal, semua itu dikarenakan semakin meningkatnya kesadaran untuk meningkatkan karakter wirausaha dalam meningkatkan ekonomi dimasa yang akan datang untuk itulah pentingnya jiwa wirausaha dikenalkan sejak dini, melalui pendidikan informal jiwa 


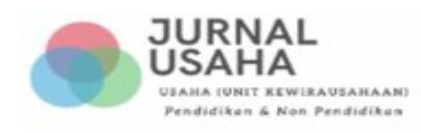

Vol 2, No. 1 (2021), Juni 2021

E-ISSN: 2746-2471, DOI:

wirausaha bisa lebih mudah dikenalkan kepada anak usia dini, karena dari keluargalah pendidikan pertama itu didapatkan, dan orangtualah yang memiliki peran penting dalam membentuk karakter dan watak anak anak mereka sejak dini agar bisa menjadi orang yang lebih mandiri, percaya diri, kreatif dan tingkah laku yang baik sehingga dari dalam diri merkalah bisa terbentuk jiwa dan mental wirausaha yang diperlukan kelak untuk masa depannya.

Pendidikan informal untuk membangkitkan jiwa kewirausahaan pada anak usia dini memang tergolong masih sedikit, bahkan penelitiannya belum banyak ditemukan namun tidak menjadi penghalang bagi para pendidik untuk bisa membantu mengarahkan peserta didiknya untuk maju dan terus berkarya, ada beberapa metode yang bisa dilakukan dalam memberikan pembelajaran informal bagi anak usia dini misalnya dengan selalu berperilaku positif, bertingkah laku baik dengan sesama teman, bisa diajak bekerjasama dan bisa beradaptasi dengan lingkungan disekitarnya, semua itu merupakan (life skills) dimana kita bisa beradaptasi dengan lingkungan dimana tempat kita tinggal. Life skills bisa diartikan sebagai ketrampilan dimana seorang individu bisa mengatasi apa yang menjadi permasalahan dalam hidupnya dan berani menerima apapun yang dihadapinya tanpa harus merasa tertekan sehingga dengan mudah bisa menjalani kehidupan ini dengan penuh rasa bahagia dan memiliki tujuan yang jelas

Kemampuan untuk menghadapi masalah dan bisa memcahkannya dengan baik itulah yang dinamakan life skills. Ketrampilan yang harus kita kembangkan adalah harus bisa mengenal diri sendiri,kita harus tau apa karakter kita kelebihan dan kekurangan apa yang kita miliki, dengan memiliki kemampuan tersebut kita akan tau dan dapat menyadari pada saat kita merasa tertekan ataupun stress sehingga dapat mengatasinya dengan baik. Ketrampilan tersebut bisa dikenalkan sejak dini dengan mengajarkan anak melalui permainan yang berkarakter ataupun beberapa game yang bisa mengasah kemampuan mereka dalam belajar memecahkan suatu masalah dalam permainan tersebut.

\section{METODE PENELITIAN}

Tulisan ini menggunakan metode pendekatan kualitatif dengan kajian deskriptif analitis dan eksplanatif. Pengumpulan data melalui studi literature, kepustakaan /dan dokumentasi (Sugiono, 2008) metode dari penelitian terdahulu dari penelitian sebelumnya yang terkait dengan pentingnya pendidikan Informal untuk mengenalkan dan menumbuhkan jiwa wirausaha, di jalur pendidikan informal fakta inilah setiap individu akan terbentuk kebiasaan, watak, tingkah dan perilakunya dimasa yang akan datang dan bahkan kewirausahaan sudah menjadi trand masa kini yang sudah banyak diajarkan pada jalur pendidikan informal seperti lembaga berbasis pesantren, dengan pengamatan tersebutlah pendidikan informal merupakan suatu hal yang tidak bisa diabaikan untuk menumbuhkan jiwa wirausaha sejak dini. 
Vol 2, No. 1 (2021), Juni 2021

E-ISSN: 2746-2471, DOI:

\section{HASIL DAN PEMBAHASAN}

Penelitian Al Muin (2017) motivasi pengembangan dan pemantapan karir di Pondok Pesantren Al Rabbani Cikeas bagi remaja yang putus sekolah, menunjukkan bahwa siswa akan dapat diarahkan dan bisa mengenal dirinya serta kemampuannya melalui bimbingan karir siswa sehingga mereka bisa memahami dan mampu meningkatkan kemampuannya masing masing untuk melatih dan merencanakan karirnya dan bisa terlatih sehingga bisa bersikap dewasa untuk menentukan karirnya. Penelitian ini dilakukan dengan memberikan penyuluhan pengembangan dan arahan kepada para siswa remaja putus sekolah dengan model pendidikan informal melalui metode pembelajaran karir, kewirausahaan dan disertai dengan praktek membuat businees plan dan produk UMKM berupa makanan burger.

Dengan demikian pendidikan kewirausahaan tidak lagi diajarkan di pendidikan formal saja seperti sekolah umum namun saat ini pendidikan kewirausahaan sudah merupakan trand masa kini yang memang sudah banyak diajarkan oleh lembaga-lembaga informal seperti lembaga berbasis pesantren. Kurikulum kegiatan belajar kewirausahaan dalam pendidikan informal akan membentuk peserta didik yang mandiri dan kreatif.

\section{Pendidikan Informal Menumbuhkan Jiwa Wirausaha Bagi Anak Usia Dini}

Pendidikan informal untuk membangkitkan jiwa kewirausahaan pada anak usia dini memang tergolong masih sedikit, bahkan penelitiannya belum banyak ditemukan namun tidak menjadi penghalang bagi para pendidik untuk bisa membantu mengarahkan paeserta didiknya untuk maju dan terus berkarya, ada beberapa metode yang bisa dilakukan dalam memberikan pembelajaran informal bagi anak usia dini misalnya dengan memberikan pendidikan ketrampilan hidup (life skills). Life skills adalah ketrampilan hidup diartikan sebagai ketrampilan yang dimiliki seseorang untuk mau dan berani menghadapi problema hidup dan penghidupan secara wajar tanpa merasa tertekan, kemudian secara proaktif dan kreatif mencari solusi hingga memiliki kemampuan mengatasinya (dirjen PLSP, Direktorat tenaga teknis:2003)

Hasil penelitian Dadang Yunus Lutfiansyah (2009) dengan tema pendidikan kecakapan hidup (life skills) dalam pemberdayaan perempuan kepala keluarga (pekka) dalam meningkatkan kemandirian dan pendapatan berwirausaha, penelitian ini bertujuan untuk memberikan kepada para peserta pelatihan bekal ketrampilan ,pengetahuan, serta kemampuan fungsional praktis dalam perubahan sikap untuk bekerja dan berusaha secara mandiri dan professional, dengan membuka lapangan kerja dan lapangan usaha serta memanfaatkan peluang yang ada sehingga dapat meningkatkan kualitas dan kesejahteraannya. Peserta pelatihan pada program pendidikan ketrampilan atau kecakapan hidup ini adalah mereka yang tamat hanya sampai Sekolah Dasar (SD) dan mereka kebanyakan perempuan yang menjadi kepala keluarga dengan kategori keluarga yang kurang mampu atau keluarga miskin. 


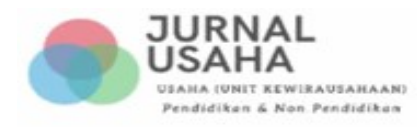

Vol 2, No. 1 (2021), Juni 2021

E-ISSN: 2746-2471, DOI:

Hasil penelitian Endang Ikhtiarti menemukan bahwa yang menjadi sorotan tajam dalam masyarakat adalah perilaku pemuda yang cenderung individualis dan kurang mendasarkan perilakunya pada nilai-nilai budaya. Tanpa disadari teknologi teknologi informasi juga turut menyebarkan pola budaya barat (westernisasi), yang ternyata dengan sangat mudah mempengaruhi sikap dan karakter generasi muda saat ini. Westernisasi yang berwujud dalam berbagai macam bentuk life style, seni, dan pola pikir telah masuk melalui berbagai macam cara, salah satunya adalah melalui media yang merupakan instrumen hasil perkembangan teknologi informasi.

Melalui kolaborasi antara bentuk life skills yaitu dengan membekali ketrampilan, pengetahuan serta kemampuan fungsional praktis dapat menjadikan perubahan sikap untuk bekerja dan berusaha mandiri dengan cara membuka lapangan kerja dan lapangan usaha dengan memanfaatkan peluang yang ada dalam meningkatkan kesejahterannya. Sementara media yang saat ini banyak di gemari anak-anak (laptop, Gaget, Hp, dan lain-lain) life style media yang sangat mendorong untuk memberikan support bagi perkembangan anak Usia saat ini, dengan perkembangan teknologi inilah orang tua harus bisa mengarahkan dengan baik agar tidak terjadi dampak buruk dengan adanya media yang bisa mempengaruhi tumbuh kembangnya seorang anak menjadi positif ataupun bisa berdampak negatif.

Berdasarkan hasil penelitian terdahulu dari para peneliti terkait dengan teori-teori konsep dan kewirausahaan, penulis analisis bahwa untuk memotivasi dan membangun jiwa wirausaha penting kiranya dibangun sejak anak usia dini, sehingga akan lebih baik serta efektif.

\section{E. SIMPULAN}

Pendidikan informal dalam keluarga merupakan pendidikan pertama yang kita dapatkan sebelum melanjutkan ke jenjang pendidikan berikutnya. Pendidikan informal dalam keluarga dan lingkungan disekitar sangat berpengaruh dalam tumbuh kembang seorang anak dalam menentukan sikap dan karakter yang dapat berpengaruh untuk kehidupannya kelak. Dengan pendidikan kewirausahaan yang diajarkan dirumah akan membentuk jiwa wirausaha yang sejak dini harus benar benar ditanamkan pada anak anak kita untuk pencapaian tujuan menjadi seorang wirausaha yang sukses nantinya.Dengan konsep bermain sambil belajar akan meningkatkan stimulasi untuk mencapai ketrampilan dalam memecahkan masalah yang dihadapinya. Kemampuan dalam memecahkan masalah itulah yang dinamakan life skills, metode yang bisa dilakukan dalam memberikan pembelajaran informal bagi anak usia dini misalnya dengan memberikan pendidikan ketrampilan hidup (life skills) tersebut. Dengan demikian pendidikan informal harus benar benar dikembangkan untuk menumbuhkan karakter jiwa wirausaha sejak dini demi tercapainya Sumber Daya Manusia yang berkualitas demi kemajuan perekonomian suatu negara. 
Vol 2, No. 1 (2021), Juni 2021

E-ISSN: 2746-2471, DOI:

\section{DAFTAR PUSTAKA}

Al Muin, N. (2017). "Motivasi Pengembangan Dan Pematangan Karir Kewirausahaan." Jurnal Sosio E-Kons 9-1.36-45, LPPM-Unindra.

Ikhtiarti, E. "Membangun Generasi Muda Smart And Good Citizenship Melalui Pembelajaran Ppkn Menghadapi Tantangan Revolusi Industri 4.0." Fakultas Keguruan Dan Ilmu Pendidikan Universitas Lampung.

Lutfiansyah, D.Y. (2009). "Pendidikan Kecakapan Hidup (Life Skills) Dalam Pemberdayaan Perempuan Kepala Keluarga (Pekka) Untuk Peningkatan Pendapatan Dan Kemandirian Berwirausaha." Jurnal Pendidikan Luar Sekolah 4(2).

Modul Kewirausahaan. (2012). "Modul Kewirausahaan."

Rusdiana.(2014). Kewirausahaan Teori Dan Praktik.Bandung : CV Pustaka Setia, hal 45

Suryaningsih, N. M. A. (2020). "Pendidikan Anak Usia Dini." Jurnal Obsesi 4(1): 187-200. http://core.ac.uk/download/pdf/270238331.

Suryana (2014). Kewirausahaan Kiat Dan Proses Menuju Sukses.Jakarta : Salemba Empat, hal 10. 